\title{
Use of indicators in River Basin Management Planning and Strategic Environmental Assessment processes
}

\section{Rosa Santos Coelho, Pedro S. Coelho, Tomás B. Ramos \& Paula Antunes}

To cite this article: Rosa Santos Coelho, Pedro S. Coelho, Tomás B. Ramos \& Paula Antunes (2018) Use of indicators in River Basin Management Planning and Strategic Environmental Assessment processes, Impact Assessment and Project Appraisal, 36:2, 155-172, DOI: 10.1080/14615517.2017.1364017

To link to this article: https://doi.org/10.1080/14615517.2017.1364017

Published online: 22 Aug 2017.

Submit your article to this journal $\sqsubset$

山 Article views: 531

Q View related articles $\sqsubset$

View Crossmark data $־$

Citing articles: 2 View citing articles $\asymp$ 


\title{
Use of indicators in River Basin Management Planning and Strategic Environmental Assessment processes
}

\author{
Rosa Santos Coelho ${ }^{a, b}$ (D), Pedro S. Coelhoc (iD, Tomás B. Ramos ${ }^{a}$ (i) and Paula Antunes ${ }^{a}$ (I) \\ aFaculdade de Ciências e Tecnologia, Departamento de Ciências e Engenharia do Ambiente, Center for Environmental and Sustainability \\ Research (CENSE), Universidade NOVA de Lisboa, Campus da Caparica, Caparica, Portugal; ' Instituto Politécnico de Santarém, Escola

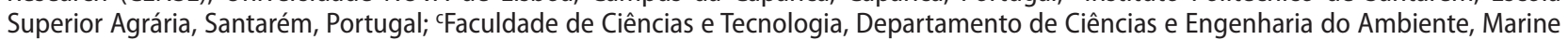 \\ and Environmental Sciences Centre (MARE), Universidade NOVA de Lisboa, Campus da Caparica, Caparica, Portugal
}

\begin{abstract}
River Basin Management Planning (RBMP) and Strategic Environmental Assessment (SEA) processes often rely on the use of indicators to assess the sustainability of planning options, to communicate with stakeholders and to support decision-making. The aim of this research was to investigate the adoption of indicators to support these processes and to analyse indicators integration between them. A conceptual framework was adopted to support a qualitative content analysis of the Portuguese RBMP and corresponding SEA reports. The main findings showed that indicators are generally used in SEA and planning reports. The analysed documents used a large number of indicators, mostly quantitative, and adopted very different approaches for their organization, selection and validation. Usually no participatory process was used in this context. The research supported the identification of areas for improvement, such as the need to promote a stronger stakeholder engagement in the indicator development process, the relevance of using standardized cross-cutting indicators and the call for the identification of a set of critical indicators to be used in both processes.
\end{abstract}

ARTICLE HISTORY

Received 16 November 2016 Accepted 20 July 2017

\section{KEYWORDS}

River Basin Management Planning; Strategic Environmental Assessment; indicators; conceptual framework; content analysis

\section{Introduction}

Water resources are one of the most significant drivers of human development (Gleick 2014). Socio-economic development, population growth and climate change determine the diverse levels of water use around the world and establish increasing pressures on water resources (Gleick 2003). Consequently, these problems have resulted in the need to implement major policy reforms at all levels of decision-making (Savenije and Van der Zaag 2008). In this context, integrated water resources management, framed as an overall policy, is becoming increasingly relevant and is often supported by public participation and sustainability-oriented approaches, while envisaging socio-economic development, physical planning and environmental protection (Savenije and Van der Zaag 2008).

Emerging water challenges are acknowledged worldwide and have triggered governments to re-evaluate their outlook on water management (Christian-Smith et al. 2012). In past decades, many countries have promoted innovative water policies and associated assessment processes (Antunes et al. 2009). In the European Union, an ambitious legal framework to support water policy was established by the Water Framework Directive (WFD), which introduced, among others, the preparation of river basin management plans for the main river basins in the European Union (European Parliament 2000).

Water resources planning is also framed by another relevant environmental policy instrument, Strategic Environmental Assessment (SEA). The purpose of SEA is to ensure that environmental considerations are fully represented and considered in decision-making processes for new plans, policies and programmes (Fischer 2003; Therivel 2004; van-Doren et al. 2013). The SEA process in the European context is framed by the European Directive 2001/42/EC.

The two directives (WFD and SEA) have different yet complementary functions, and they can have synergistic effects (Carter and Howe 2006; Larsen and Kørnøv 2009). The two instruments share important requirements, namely, in terms of data collection, evaluation of alternatives and options, assessment of policies, suggestions for mitigation actions, development of monitoring procedures, and the implementation of appropriate consultation and public participation processes. Carter and Howe (2006) highlight the benefits of exploring the relationship between the WFD and SEA Directives in the context of encouraging the sustainable use and management of water resources. 
Indicators are often considered a key element to support both SEA and planning processes (Donnelly et al. 2007; Garfi and Ferrer-Martí 2011). Indicators are special signs that communicate value-added messages to stakeholders in a simplified and useful manner, and they can be derived from a single variable to reflect some attribute or from an aggregation of several variables (Ramos et al. 2004; Ramos and Caeiro 2010). Indicators are used for different purposes (Wong 2005; Morse 2013), such as collecting, processing and using information. Indicators should be developed to add value and to transform information into intelligence and to convey messages with meaning for political action and for the public (Therivel 2004; Wong 2005; Donnelly et al. 2007; Gao et al. 2013a). When properly developed and used, indicators have the potential for effective communication with the general public and decision-makers and for supporting informed decision-making and guiding policy (Donnelly et al. 2007; Niemeijer and de Groot 2008; Mascarenhas et al. 2015). According to Wong (2005), the decision-making paradigm is increasingly strategic and less operational and the focus of the indicators to follow this trend has shifted from a simple and direct approach to complex methodological models of indicator construction. Indicators are also used to measure progress and monitor feedback mechanisms (Donnelly et al. 2007; Niemeijer and de Groot 2008; Mascarenhas et al. 2015) as they provide a platform for involvement, discussion and deliberation (Gao et al. 2013b).

Several authors note the need to use criteria for indicator selection (OECD 1993; Ramos et al. 2004; Therivel 2004; Donnelly et al. 2007; Ramos 2009) and to evaluate the usefulness and robustness of different sets of criteria (Mascarenhas et al. 2012, 2015). Niemeijer and de Groot (2008) present the importance of using causality chains of cause and effect as a way to help structure and understand reality through the use of indicators. Although causal chains are often presented as models for selecting indicators, Niemeijer and de Groot (2008) report that these structures are often used to promote the presentation of indicators rather than to support the formal indicator selection process. According to the same authors, individual criteria, such as the SMART (specific, measurable, relevant and time-bound) model proposed by Schomaker (1997) and the model defined by OECD (policy relevance, analytical soundness and measurability) (OECD 1993), are often used to support the selection process. These criteria are tested in each indicator and confer crucial characteristics for its particular function in the process but do not relate it to the other indicators or to the specific context of the evaluation (Niemeijer and de Groot 2008). Wong (2005) and Mascarenhas et al. (2015) state that isolated indicators are generally pieces of information with low added value and do not convey meaningful messages.

Other key aspects for the construction and applicability of indicators are the type of data used (Ramos et al.
2004; Wong 2005) and its availability, accuracy and validity. The entities that supply data are also considered by Wong (2005) as important factors in indicator construction, selection and updating. Documentation and technical notes related to the construction or selection of each indicator should be made available to interested parties to provide a better understanding of their meaning and to enable the assessment of data availability, as well as the costs incurred to update the indicators (European Environment Agency 2005; Donnelly et al. 2007).

Regarding the use of indicators in the planning and SEA processes, Donnelly et al. (2007) and Gao et al. (2010) note that the number of studies focused on indicators in the SEA process is limited, and they encourage research aimed at identifying and assessing the potential of indicators to support planning, assessment, decision-making and monitoring. Cloquell-Ballester et al. (2006) report that it is not usually possible to use a set of existing indicators to support planning and SEA processes for all purposes. In line with this argument, Donnelly et al. (2008) emphasize the need to establish appropriate indicators that do not only fit the specific goals of each intervention but also communicate complex phenomena in a simple manner, enabling stakeholders to develop an informed opinion. Carefully selected indicators provide a mechanism to control whether the objectives and targets are attained and thus facilitate monitoring of the environmental impacts of plan implementation (Donnelly et al. 2006a; d'Auria and Cinnéide 2009). d'Auria and Cinnéide (2009) also stress that robust indicators provide an opportunity to identify appropriate stakeholders, check the accessibility and quality of data, evaluate alternatives and their potential impacts, identify conflicts and determine a set of appropriate methods and techniques to address significant environmental issues in the area of the plan. They also note that numerous lists of pre-selected indicators may be useful but may also restrict and influence planning and SEA professionals and prevent the development of tailor-made approaches.

Donnelly et al. (2007) state, as advocated above by other specialists, that the selection and development of indicators to support the planning and SEA processes should be based on a set of fundamental criteria to ensure that indicators perform the functions for which they were created and do not produce a biased analysis of the results. In addition, by standardizing the criteria, the indicator selection process should be more streamlined, costs should be reduced, duplication of effort should be minimized and consistency ensured, increasing the benefits of indicators.

In this context, where the use of indicators in planning and SEA is still underexplored, as discussed above, the research described in this paper was mainly focused on studying the adoption of indicators for the planning of water resources and associated SEA processes, as well as on the analysis of indicator integration between both processes. The specific objectives of this research are 
threefold: (i) to search for evidence on the use of indicators in water resources planning and SEA processes; (ii) to assess whether the use of indicators in water resources planning and SEA documents show evidence of contribution to crucial functions (characterization and evaluation, communication, decision-making and monitoring); (iii) to check the criteria used for selecting and developing indicators.

To meet the research aim, a conceptual framework, containing the main criteria considered relevant to analyse the use of indicators in River Basin Management Planning (RBMP) and SEA processes, as supported by a literature review, was developed. This framework was used to conduct a content analysis (CA) of the use of indicators in the Portuguese RBMP and SEA reports. This analysis was undertaken in the scope of the WFD requirements, providing relevant and timely information on this matter.

The following sections describe the conceptual framework developed to support the analysis (Section 2), the methods upon which that analysis was based (Section 3), a discussion of the results (Section 4), and finally the main conclusions and recommendations for future developments (Section 5).

\section{Methods}

\subsection{Conceptual framework}

The use of a set of indicators is seen as a relevant methodology to evaluate the objectives for RBMP as envisaged in the WFD, which has been gaining increasing relevance (Carter and Howe 2006; Donnelly et al. 2006a; Valenzuela Montes and Matarán Ruiz 2008; European Communities 2009). European and Portuguese legislation does not explicitly require the definition and use of indicators in planning and SEA processes (European Parliament 2001). Nevertheless, there are several reference documents that identify or provide recommendations for the use of indicators to support these processes (Therivel 2004; OECD 2006; Fischer 2007; World Bank 2007, 2011; European Communities 2009; Partidário 2012; European Commission 2013).

The conceptual framework (Table 1) presents a selection of the key aspects and features of indicators, as explored by the literature; additionally, it presents a set of associated criteria developed for the analysis of indicators in planning and SEA processes. This framework is organized around four main clusters of criteria, each one with its own rationale and operational coherence.

The four main clusters are the following: (a) Organization, selection and validation of indicators; (b) Relevance of indicators to promote communication with stakeholders and to support decision-making; (c) Basic information for indicator construction and updating; and (d) Integrating indicators into plans and SEA processes. Each group summarizes key aspects and features for indicator design and use in planning and related environmental assessments (plans and SEA documents). The rationale for each criterion is supported by the indicated references.

\subsection{Case study}

The conceptual framework described in the previous section (Table 1) was used to support research of the several documents that comprise the RBMP in Portugal and the corresponding SEA reports.

The analysed documents (dated from 2012, except the Madeira RBMP (RH10), dated from April 2014), were prepared under the scope of the current legal national and European context (European Parliament 2000; European Parliament 2001; Lei n 58/2005 2005; Portaria 1284/2009 19 de Outubro 2009). The analysed plans include the Technical Reports (TR) of the 10 River Basin Districts and the River Basin Plan (RBP) of Ribeiras do Oeste (RO), as well as the associated SEA main documents, considered as Supplementary Procedural Reports, which comprise the Environmental Report (ER), Non-technical Summary (NTS), Public Participation Report (PPR) and Decision Making Support Information System (DM.SIS). The SEA Scoping Reports (SR) were also analysed. The Environmental Statements (ES) were not reviewed as they were not available at the time the analysis was conducted.

As stated in the WFD, the main spatial unit for river basin management is the River Basin District (RBD). Table 2 presents the structure of the Portuguese RBD, framed by River Basin (RB) and River Basin District Administrations (RBDA), ${ }^{1}$ and Figure 1 presents the spatial organization of the Portuguese water management system, which includes 10 RBD. The Portuguese authorities in charge of RBD management are the RBDA.

\subsection{Content analysis}

The document research was based on the CA technique, defined by Krippendorff (2003, p. 10) as a'research technique for making replicable and valid inferences from data to their context'. The method consists of a 'set of methods for analysing the symbolic content of any [written] communication. The basic idea is to reduce the total content of a communication to a set of categories that represent some characteristic of research interest' (Norton 2008, p. 433).

CA is a very transparent research method that can be applied to a wide variety of documents, although the validity of the results depends on the quality of the documents reviewed, including their credibility, authenticity, representation and availability (Bryman 2012).

The approach adopted for this research also considered the particular works conducted by GAO (1996) and Neuendorf (2002), which mainly focused on indicators and their assignments and implications for water 


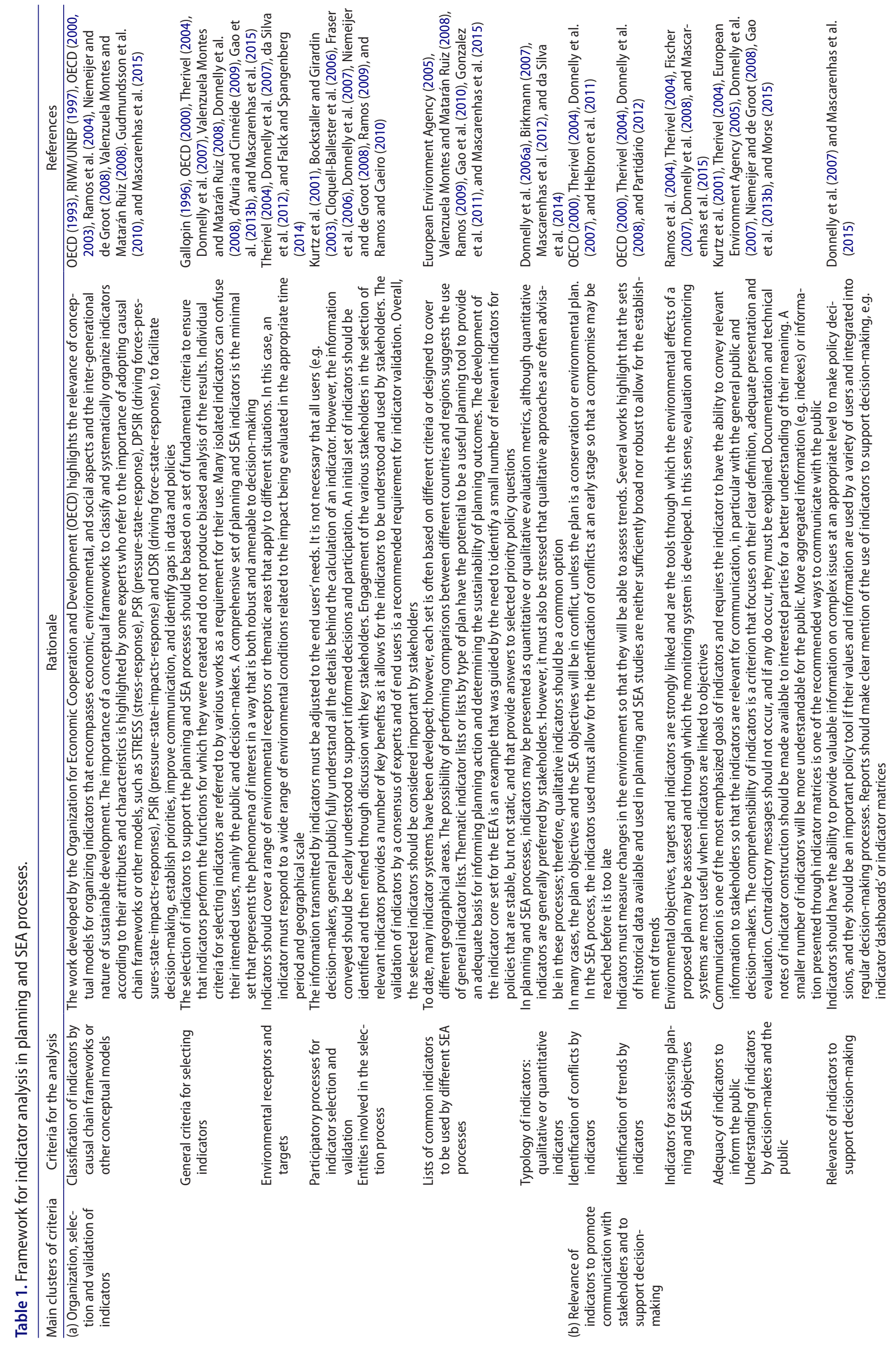



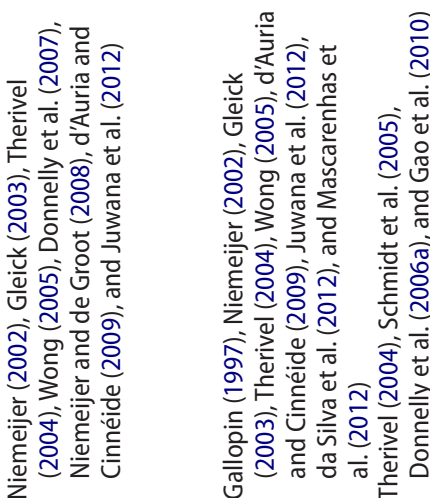

를 흔

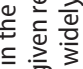

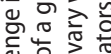

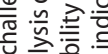

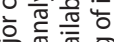

है

东充至

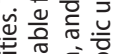

产

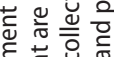

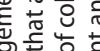

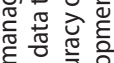

을 矛

중

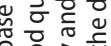

윰 융

응 융 웡. 응

을 흥 뉸

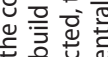

$\cong$ 정

후웡

苋芯豞

元

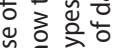

约高

뜬

응 웜

ํํㄹ है

凶ั응

岂苋苋

등으ㅇㅝㅠ웡

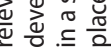

<

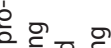

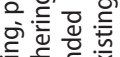

要

党苨

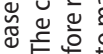

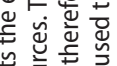

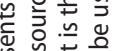

递

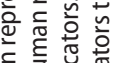

은

害熍

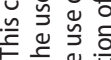

定

就

들

穿容

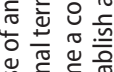

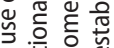

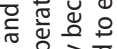

등 응 중무

过 둥

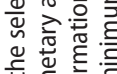

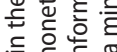

눙워

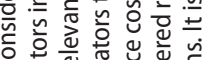

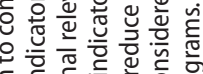

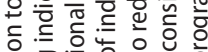

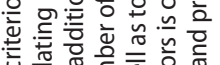

\section{$\stackrel{\square}{ \pm}$}

욜

o ᄒᄒ

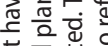

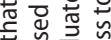

政

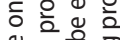

济

궁

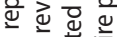

둥 핳

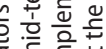

하의

政

跣

票 要

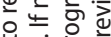

둔음

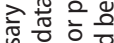

还

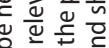

즉

응 늉

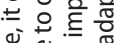

政

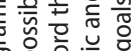

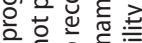

列

든

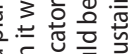

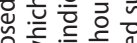

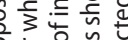

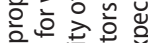

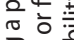

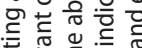

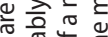

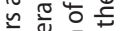

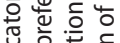

흘 흘

동흔 흥

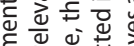

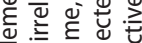

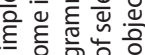

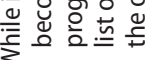
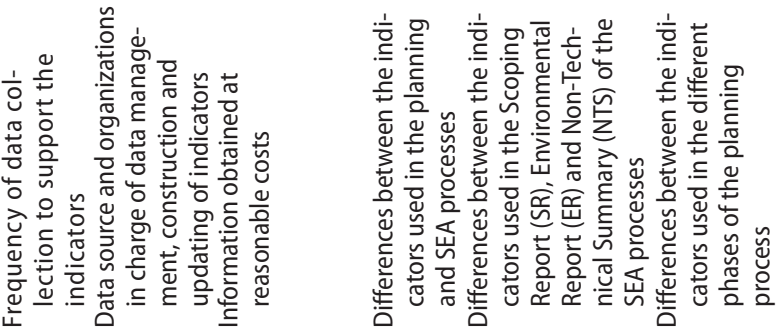

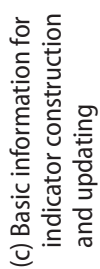

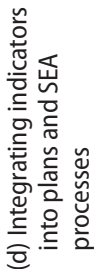

Table 2. Portuguese River Basin Districts.

\begin{tabular}{lcl}
\hline $\begin{array}{l}\text { River Basin District } \\
\text { Administrations (RBDA) }\end{array}$ & $\begin{array}{c}\text { River Basin Districts } \\
\text { (RBD) }\end{array}$ & \multicolumn{1}{c}{ River Basins (RB) } \\
\hline ARH Norte & $\mathrm{RH} 1$ & Minho/Lima \\
& $\mathrm{RH} 2$ & Cávado/Ave/Leça \\
& $\mathrm{RH} 3$ & Douro \\
ARH Centro & $\mathrm{RH} 4$ & Vouga/Mondego/Lis \\
ARH Tejo & $\mathrm{RH} 5$ & Ribeiras do Oeste \\
& & Tejo \\
ARH Alentejo & $\mathrm{RH} 6$ & Sado/Mira \\
& $\mathrm{RH} 7$ & Guadiana \\
ARH Algarve & $\mathrm{RH} 8$ & Ribeiras do Algarve \\
ARH Açores & $\mathrm{RH} 9$ & Açores \\
ARH Madeira & $\mathrm{RH} 10$ & Madeira \\
\hline
\end{tabular}

resources plans. The CA was mainly qualitative and was based on the definition of variables or criteria (information that the appraiser searches for), categories (possible answers that should be mutually exclusive), and analysis of the selection of material and recording units (portions of text to analyse) (GAO 1996; Neuendorf 2002; Krippendorff 2003).

The CA process started with a detailed verification of each reference to the keyword 'indicator' in each of the reports (TR and NTS indicators in the planning process and SR, ER, NTS and PPR indicators in the related SEA processes). The analysed reports constituted the recording units and established the support for the code assigned to each occurrence of the keyword.

\section{Results and discussion}

The main results obtained from the $C A$ are presented in Tables 3-6, organized according to the four main clusters included in the framework.

After CA was performed, it was possible to highlight that complete information to support the evaluation to relate indicators and criteria of analysis was mainly available in the TR and ER documents. In the remaining documents (SR, NTS, PPR and DM.SIS), the associations between the indicator sets included in those documents and the indicators used in the TR and ER were analysed.

\subsection{Organization, selection and validation of indicators}

The different RBD followed very different strategies for the organization, selection and validation of indicators, and several RBMP mentioned a variety of criteria for indicator selection, although their procedures were not explicitly described. Supporting guidance documentation and the adopted technical steps, indicating how the indicator was constructed and used, should be clearly stated to the interested parties to enable better understanding of its meaning (Therivel 2004; Donnelly et al. 2007; Gao et al. 2013a).

According to Gallopin (1997), Kurtz et al. (2001) and Donnelly et al. (2007), public participation in the selection of indicators is highly desirable as an obligation of a 


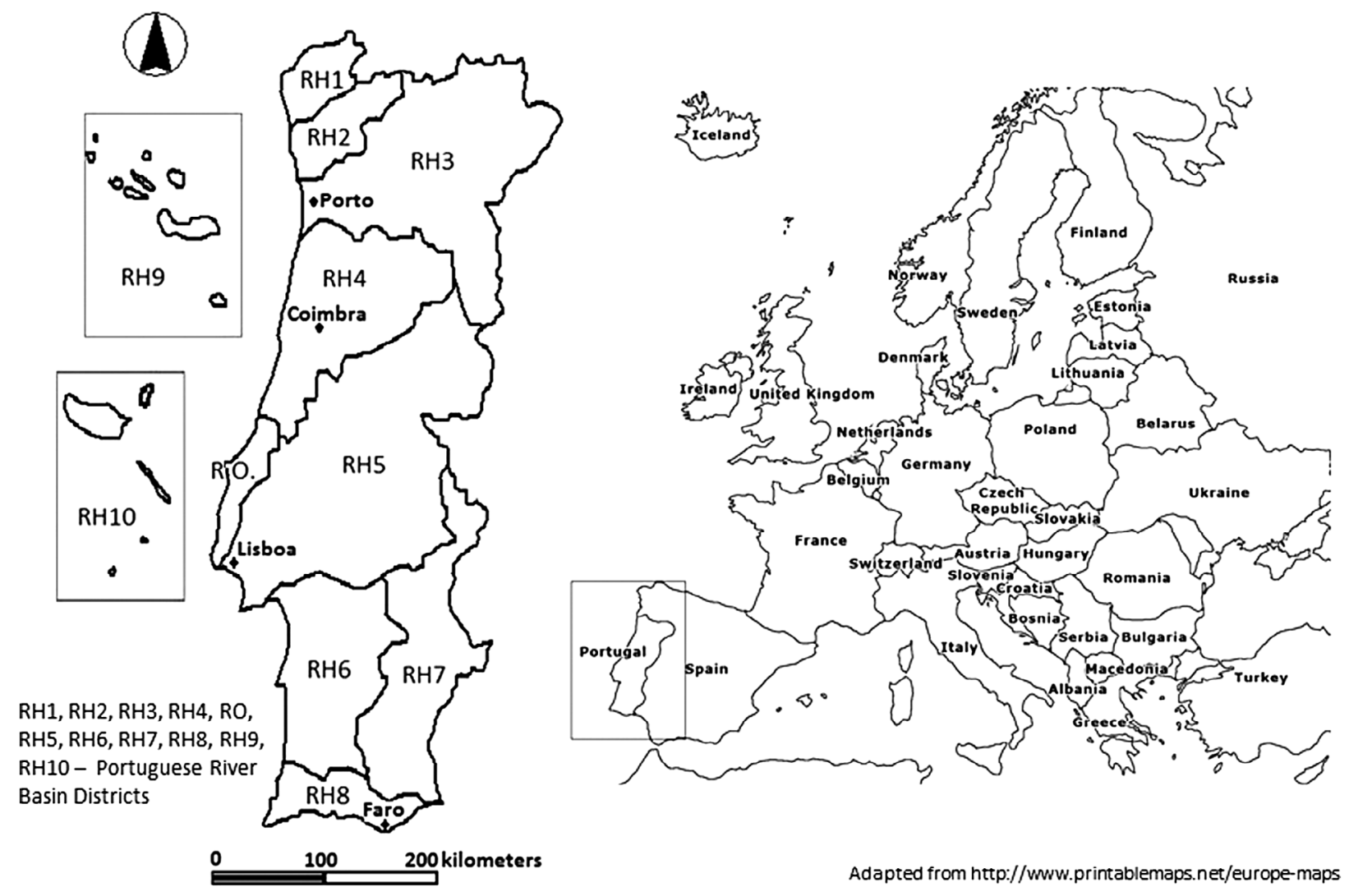

Figure 1. Portuguese River Basin Districts. Adapted from http://www.printablemaps.net/europe-maps

society looking for sustainable development. Bockstaller and Girardin (2003), Cloquell-Ballester et al. (2006) and Ramos (2009) also state that the indicator sets used in any evaluation process must be previously validated and approved by stakeholders. On the other hand, indicators that are not adjusted by stakeholders could be considered not useful and consequently not used (Mascarenhas et al. 2015). Overall, there were no references in the analysed documents to support the existence of indicator validation, with or without the use of participatory processes. However, as previously mentioned in Table 3, the proposed list of indicators identified in the scoping SEA reports was reviewed by the environmental public authorities, which determine the scope and level of detail of the information that must be included in the ER. In some cases, the indicators used in the ER were not exactly coincident with the indicators proposed in the SR. This was not necessarily a result of the environmental public authorities recommendations but may indicate that the technicians of the SEA process used relevant comments or recommendations to promote the self-validation process of the indicators (Cloquell-Ballester et al. 2006).

The majority of the indicators used in the analysed documents were quantitative, enabling a more detailed analysis of the evolution of each goal set against the proposed targets defined in the planning and SEA process. As stated by Gao et al. (2014) and da Silva et al. (2014), the use of quantitative indicators is generally prioritized in relation to qualitative indicators in the processes of planning and SEA. According to Therivel (2004) and Donnelly et al. (2006a), qualitative indicators are more subjective and more difficult to operationalize, although they may communicate relevant information.

All RBMP and SEA processes were based on a large number of indicators (Tables 7 and 8 ) and did not follow the recommendations made by Birkmann (2003), Donnelly et al. (2006a) and Ramos and Caeiro (2010). The large number of indicators used in the majority of assessment processes can be a problem, particularly for the implementation of the monitoring programme (Birkmann 2003).

Ramos et al. (2004), Donnelly et al. (2007) and Falck and Spangenberg (2014) stressed that indicators should cover a range of environmental receptors and should apply to different situations. When indicators cover issues identified as important from a scientific point of view and based on stakeholder concerns, the monitoring systems will be more effective. In the analysed reports, indicators were organized by environmental issue, in either the planning process or in their SEA. In each RBD, the organization of SEA indicators considered the environmental factors set out in the SEA Directive (Annex I of the Directive presents a list of twelve environmental issues and their relations), although the adopted thematic classification varies among the different RBD. The theme 'vulnerabilities and risks' was common to all SEA reports. This theme and the'resources' theme presented 


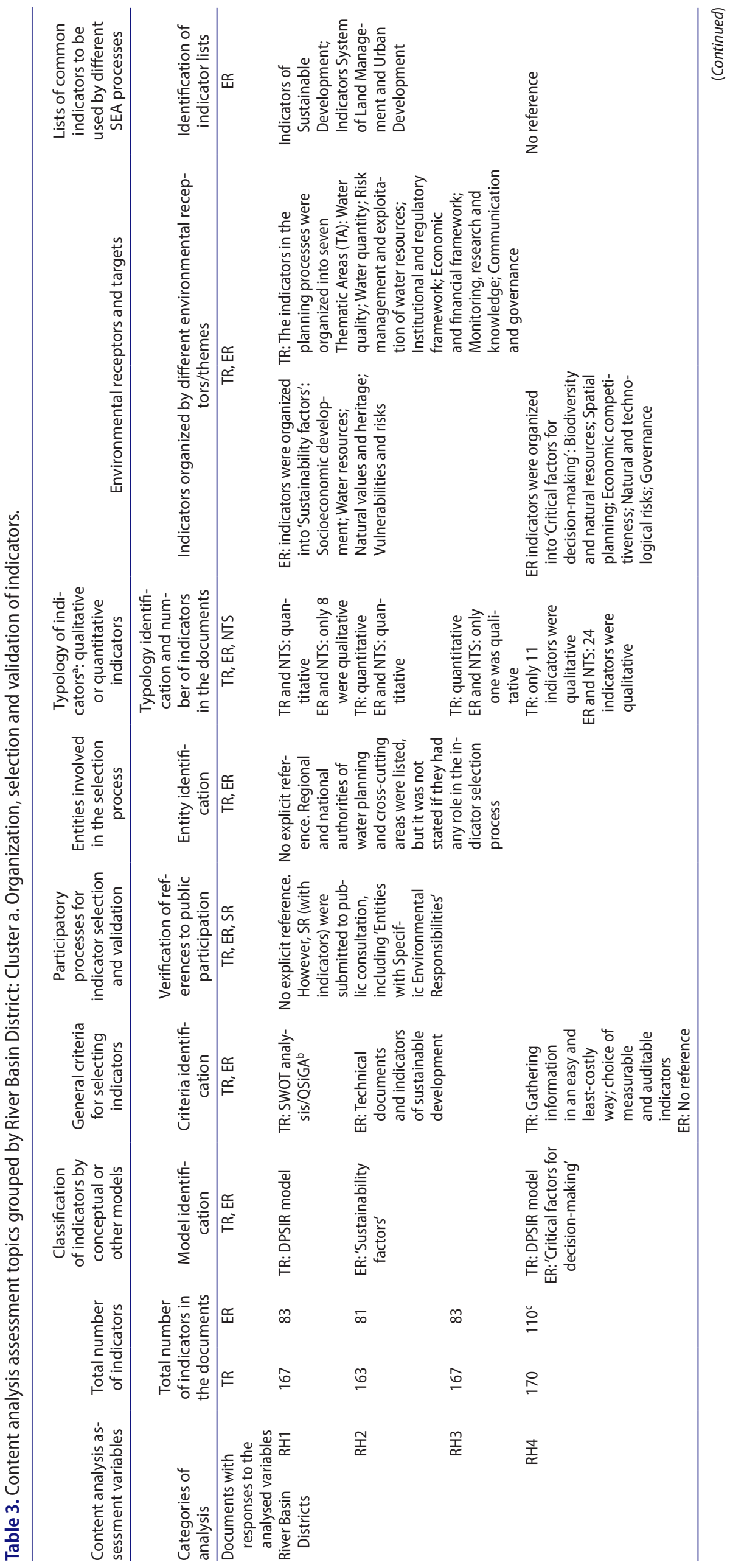




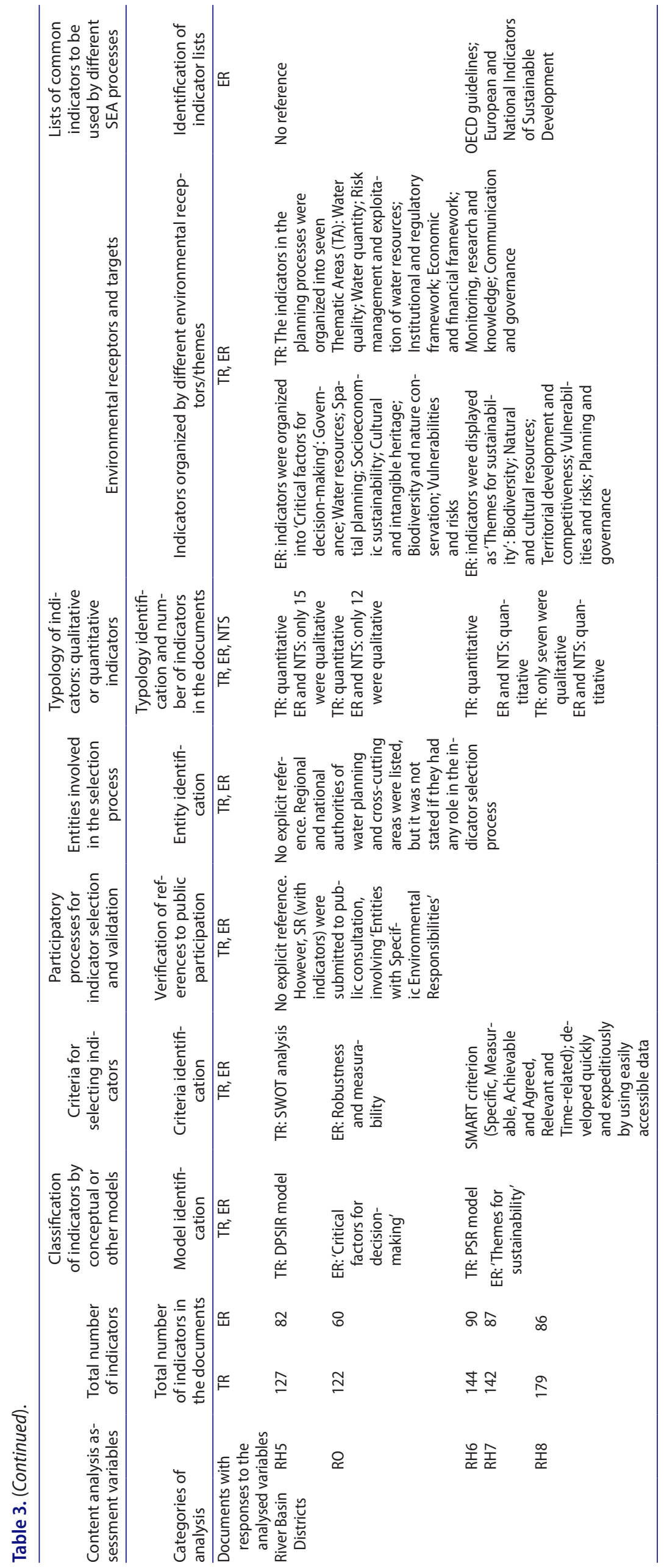




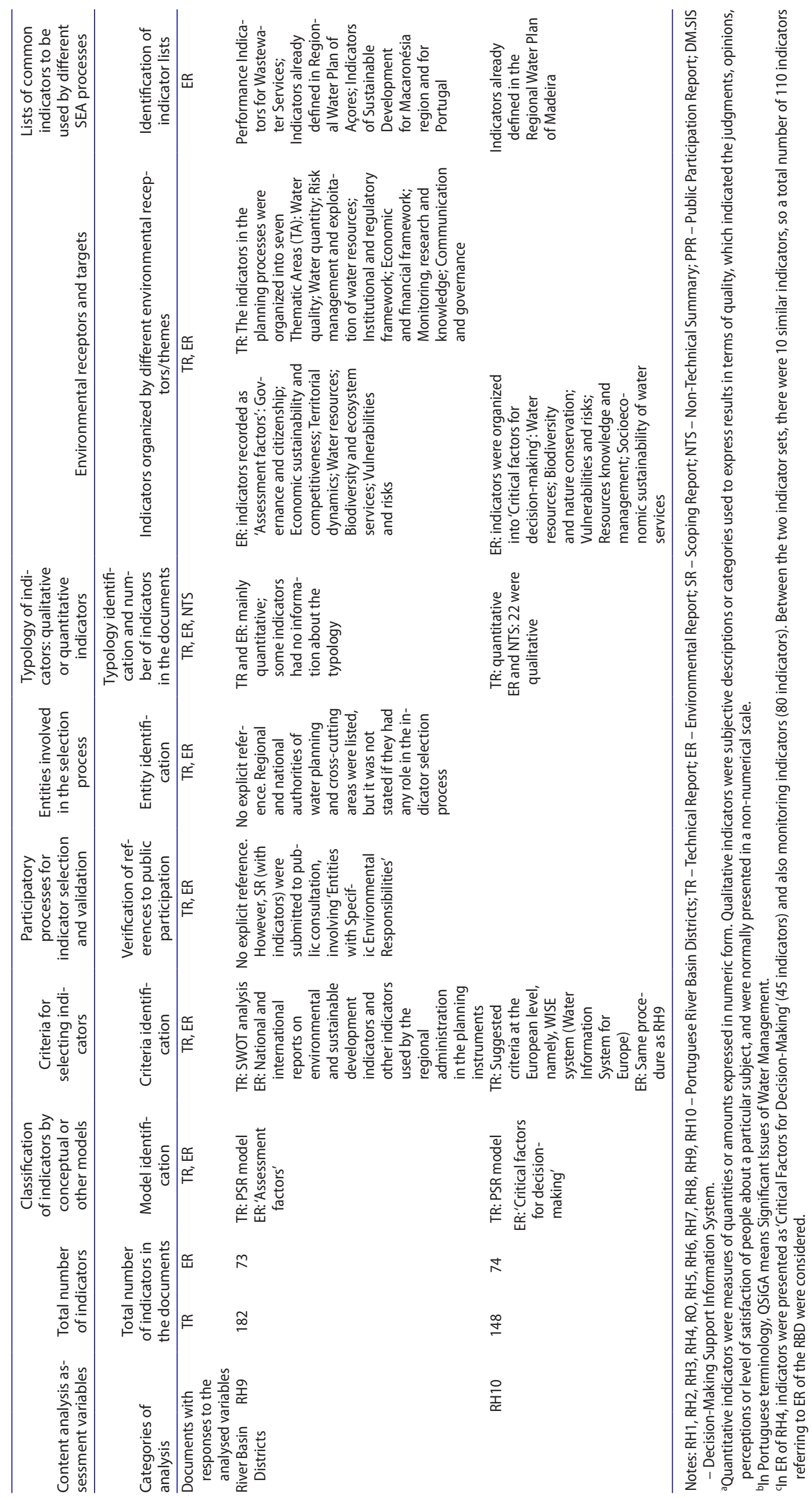




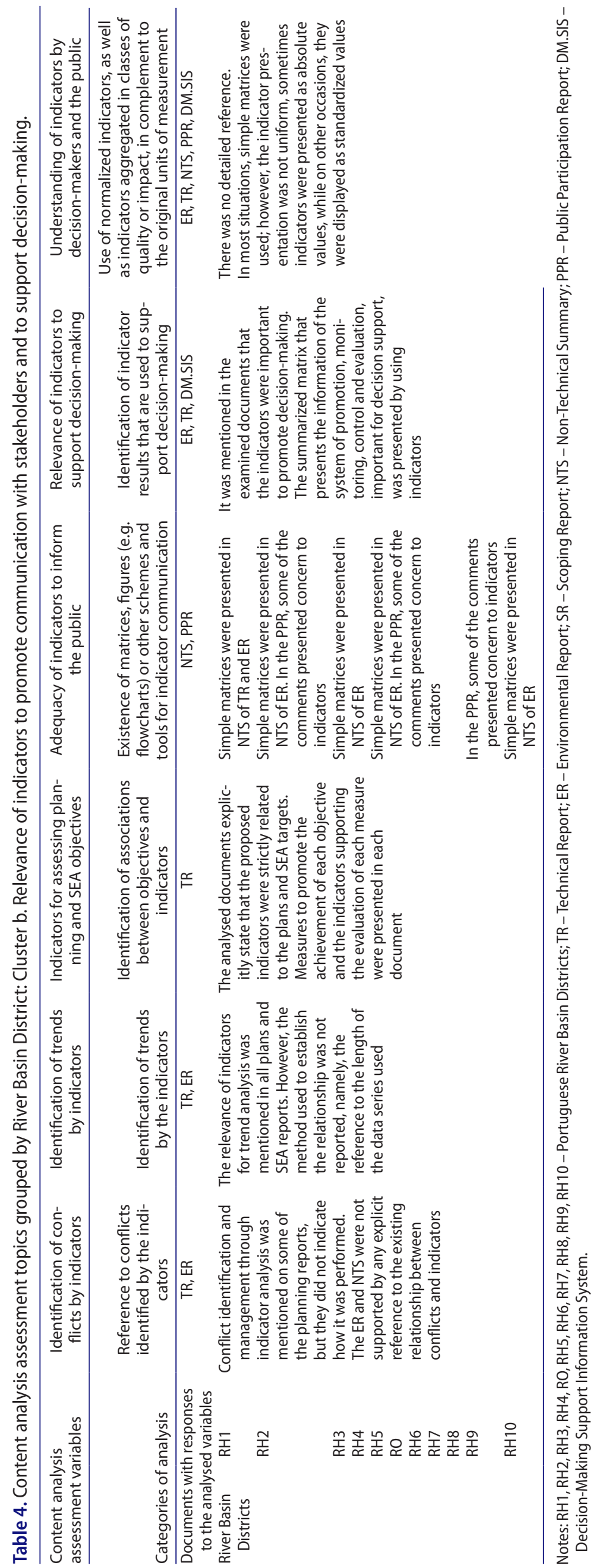



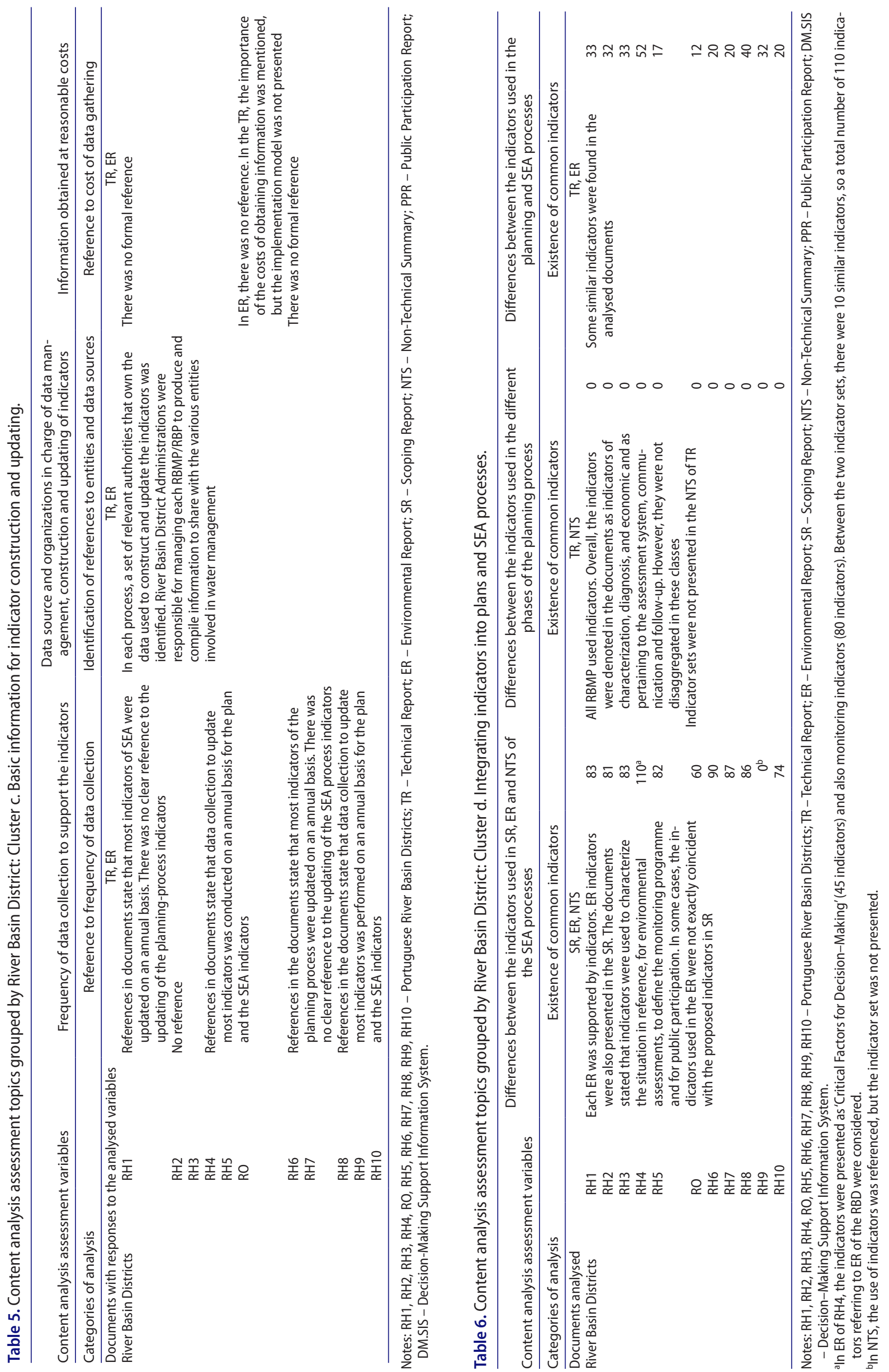


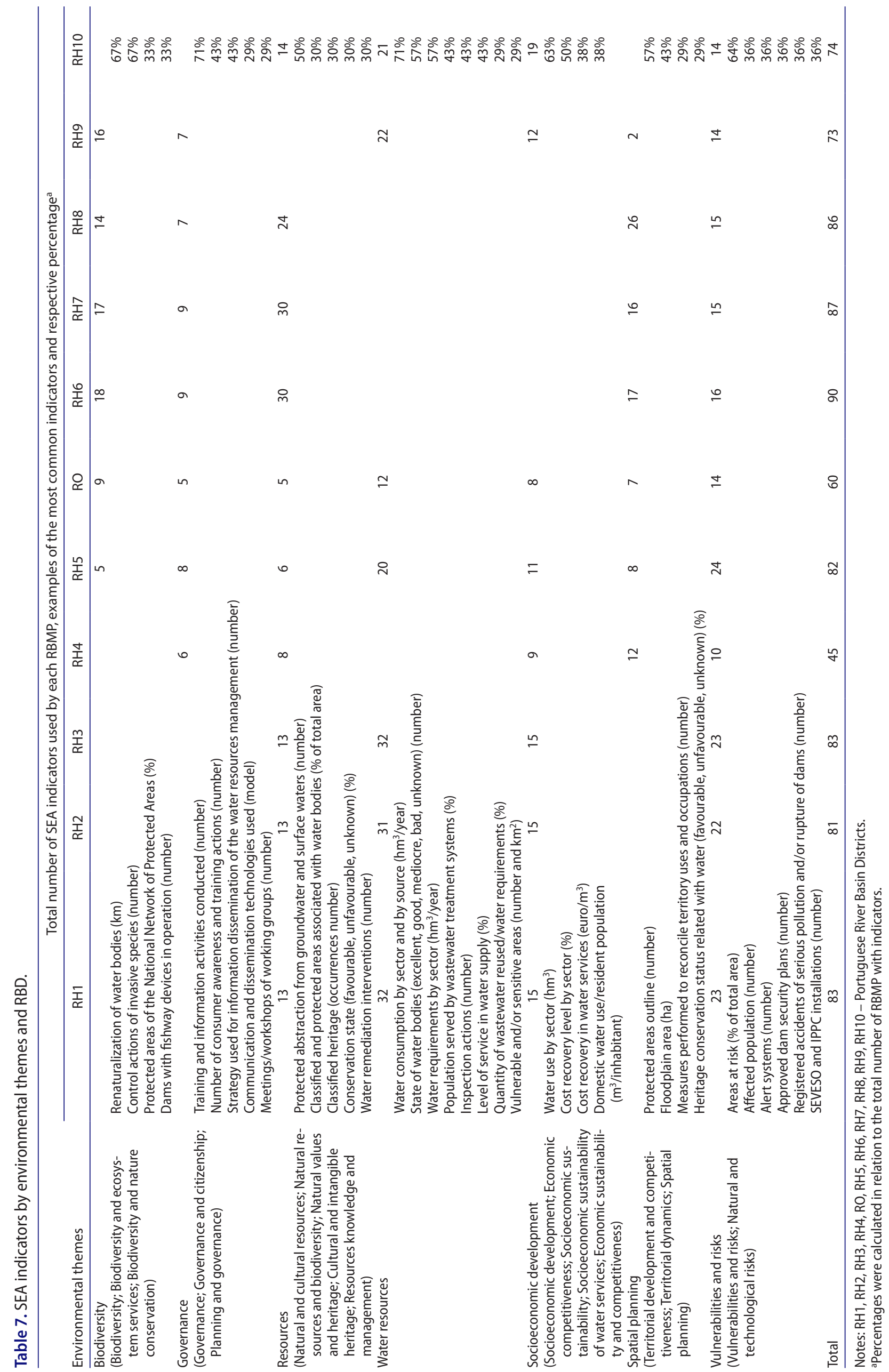




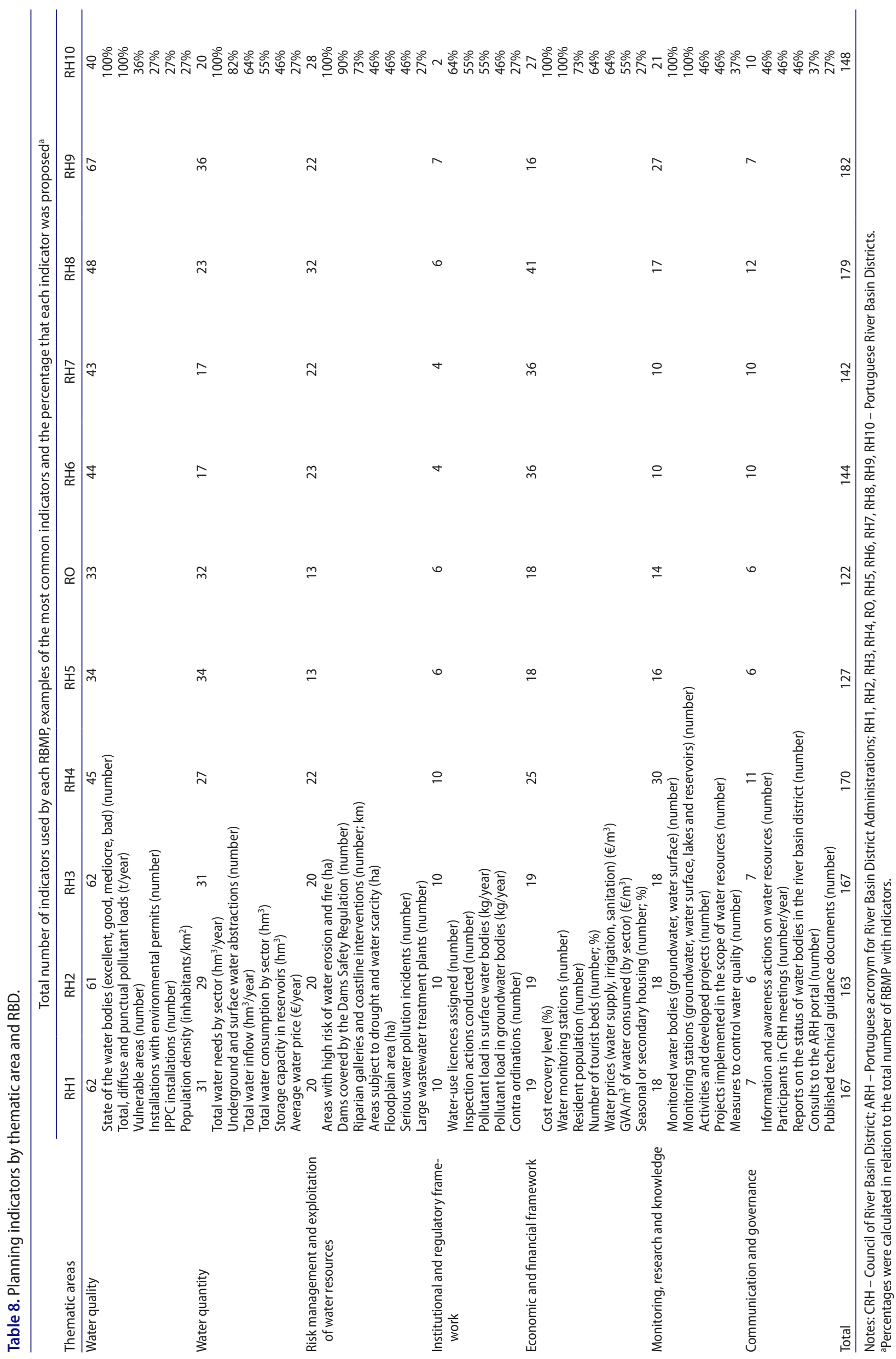


the highest number of indicators. Indicators related to water resources socio-economic development were also common. In the ER of RH4, a specific set of expost monitoring indicators was presented. Ex post monitoring indicators were not specifically identified in the other RBD. Table 7 presents the SEA indicators organized according to environmental receptors, the total number of indicators in each category and examples of the most frequently used indicators.

In the RBMP reports, indicators were organized into seven thematic categories. Table 8 presents the indicators used in the plans, organized into thematic areas. The thematic areas 'water quality' and 'water quantity' presented the highest number of indicators. To characterize, evaluate and follow-up the 'water quality', approximately $30 \%$ of the total number of indicators were used in all the RBD. The characterization of 'water quantity' was supported by a large number of indicators, whose percentage ranged from $27 \%$ in $\mathrm{RH} 5$ to $12 \%$ in $\mathrm{RH} 6$ and RH7. The indicators integrated in the theme'institutional and regulatory framework' appeared in smaller numbers, approximately $4 \%$ of the total for all RBD, similar to the indicators of 'communication and governance' $(4 \%)$ in the north and Açores RBDA (ARH Norte e ARH Açores).

In the RBMP reports, indicators were mainly structured through the conceptual DPSIR (RIVM/UNEP 1997) and PSR (OECD 1993) models, although this requirement was not established in the official guidance documents nor in the legal framework.

Figure 2 presents the number of indicators used in the planning process for each RBD and the adopted conceptual model. The adopted indicator models varied between RBD (DPSIR and PSR models). The number of indicators used in each component of the conceptual model also varied between RBD, although, on average, there was a balance between the three components of the PSR model. On average, pressure indicators represented $30 \%$ of the total number of indicators (minimum and maximum of 39 and 60 indicators); state indicators (minimum and maximum of 30 and 81 ) and response indicators (minimum and maximum of 32 and maximum 79 ) each corresponded to $27 \%$ of the total number of indicators. The impact indicators in the DPSIR model represented $4 \%$ of the total number of indicators. Matondo (2002), Valenzuela Montes and Matarán Ruiz (2008), Helbron et al. (2011) and Juwana et al. (2012) stress the importance of using similarly structured indicator models to enable comparative analyses and to support cohesive and global decision-making.

\subsection{Relevance of indicators to promote communication with stakeholders and to support decision-making}

The analysed documents explicitly state that the indicators used were strictly related to the plans and SEA objectives and targets, in line with the recommendations of Donnelly et al. (2006a).

The relevance of the indicators for trend analysis was mentioned in all RBMP and SEA reports. The possibility of identifying and managing conflicts between planning and environmental assessment objectives by using indicators was also mentioned in some of the planning and SEA reports. However, the methodology and the set of indicators that could support this analysis were not mentioned. In this context, Donnelly et al. (2007) and Helbron et al. (2011) recommended that the set of indicators used in environmental assessment must allow the identification of conflicts in early stages of the planning process to reach a compromise between the planning and SEA objectives before it is too late.

Communication is one of the most emphasized goals of the indicators (European Environment Agency 2005; Niemeijer and de Groot 2008; Gao et al. 2013a).

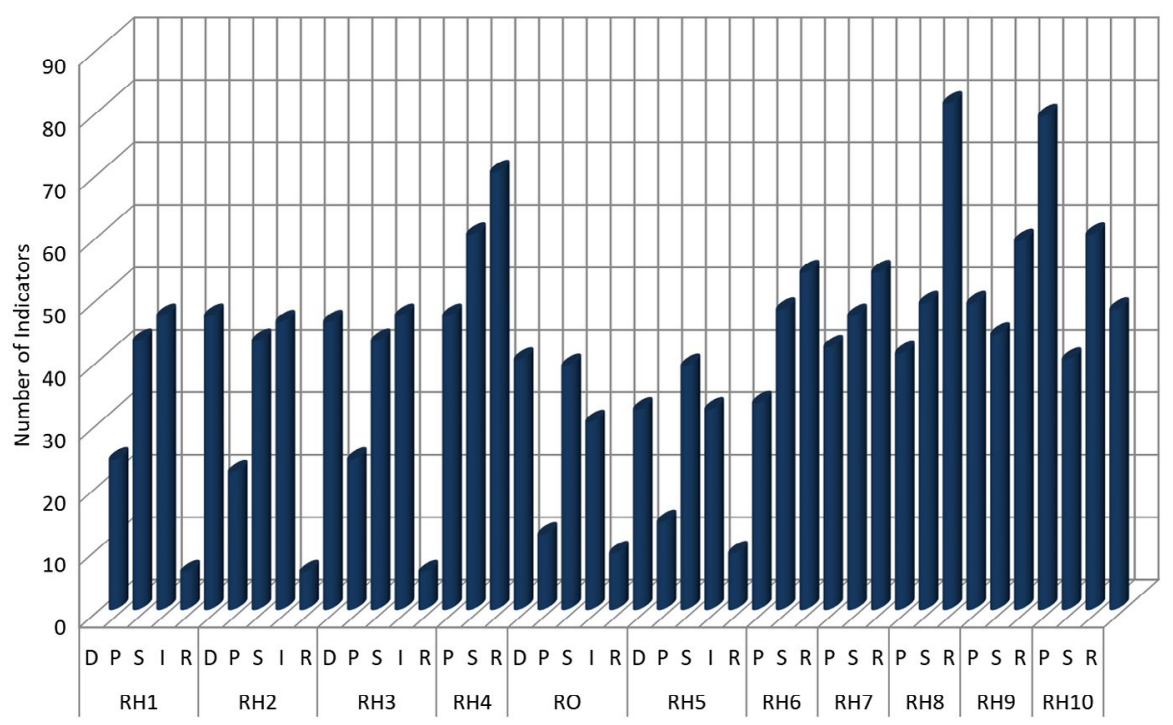

Figure 2. Number of indicators in the planning process in each RBD and conceptual model. 


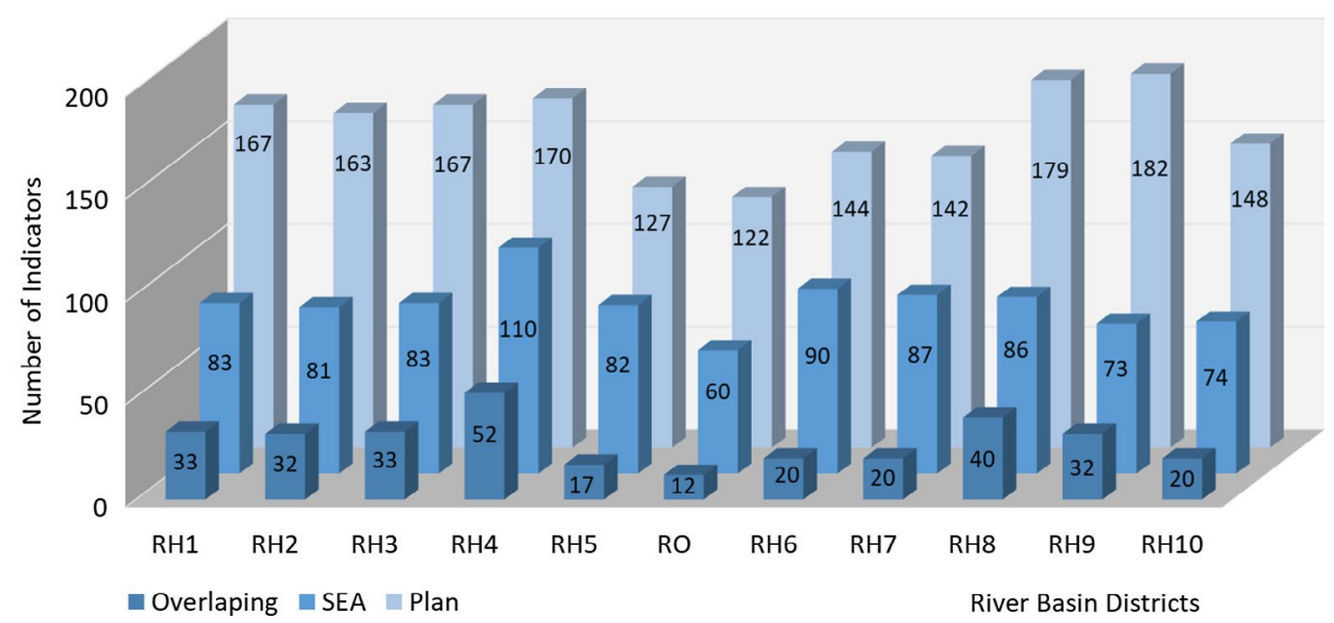

Figure 3. Planning and SEA processes indicators for all River Basin Districts.

Communicating information to the public based on indicators was often mentioned and emphasized in the TR, ER, NTS and PPR. However, there was no explicit reference to the relevance of the indicators for the public participation process. The indicator sets mentioned in the TR and ER were not listed in all NTS, although NTS are the main documents consulted by the public in the consultation processes and are used to communicate the key findings of the technical and environmental reports (Bonde and Cherp 2000; European Parliament 2001; European Communities 2009). On the other hand, some of the contributions submitted by public authorities and other actors reported the indicators, which suggests that the indicators were used in the public participation stage in some situations.

Gallopin (1997), Niemeijer and de Groot (2008) and Mascarenhas et al. (2015) state that the most important feature of indicators, compared to other forms of information, is their relevance to policy and decisionmaking. In the majority of the technical and environmental reports for RBMP and SEA processes, the relevant information, including objectives, measures, recommendations for implementation and goals, were presented in a final summary matrix based mainly on the indicators. The adoption of this technique is an important step to support an informed decision-making process, as suggested by Ramos et al. (2004), Therivel (2004), Donnelly et al. (2006b) and Gao et al. (2013b).

\subsection{Basic information for indicator construction and updating}

In all the analysed documents, sets of entities with responsibilities in the coverage area of each plan were identified. In particular, RBDA were responsible for managing each RBMP/RBP to produce and compile information to share with the various entities involved in water management. However, it was not always clearly indicated who was responsible for providing data and information to build and update the plan and SEA indicators.
In the plans and SEA reports, the frequency with which data were collected to update the indicator sets was not always presented; however, most indicators included data collection on an annual basis. This annual pattern follows the suggestion of Therivel (2004) and Niemeijer and de Groot (2008), who stress that data collection should be conducted on an annual basis. However, for some indicators, this rule does not apply.

The cost of data collection was not reported in the TR or ER. However, in some cases, the importance of easy and non-expensive data collection was highlighted, although there was no reference about the operationalization of this criterion. This aspect is one of the concerns identified by Wong (2005) for indicator updating. Mascarenhas et al. (2012) report that the cost criterion represent the ease with which data can be retrieved and used to update indicators in economic, logistical and human resources terms and should be one of the main elements considered in the indicator selection process. (Ramos and Caeiro 2010) state that the costs associated with the implementation of indicators should be anticipated. The cost/benefit ratio of each indicator should be reasonable since the cost may be a constraint to maintaining an existing indicator or adding a new indicator.

\subsection{Integrating indicators into plans and SEA processes}

In the majority of cases, the indicators did not show important differences between the planning process and the corresponding SEA. This result was mainly supported by the overlap between the two groups of indicators and by the verification of the main features and properties. However, the cross-comparison was not simple since the terminologies used were not fully compatible, raising doubts during the analysis. In addition, the indicator measurement units were not the same in many situations. The overlap rate ranged from $20 \%$ for the RBP of $\mathrm{RO}$ to $47 \%$ for RH4. Figure 3 presents the overlapped indicators between processes. It should be stressed that 
the overlap between planning and SEA indicators is a major challenge for the integration of SEA requirements and planning processes, according to Therivel (2004), Schmidt et al. (2005), Donnelly et al. (2006b), Fischer and Phylip-Jones (2008) and Gao et al. (2010).

In the RBMP reports, indicators are designated as indicators of 'characterization, evaluation, communication and monitoring'. However, the indicators presented in the documents were not specifically disaggregated according to the abovementioned categories. If the presentation of the indicators for each river basin district followed a typological presentation model and identified, for example, the monitoring indicators of the plans and the SEA process, it would be possible to assess, in detail, the capacity for integration of environmental concerns into the planning processes. In the NTS of TR, references were made to the relevance of indicators to the planning process, but the set of indicators used in the planning process was not presented.

SEA reports stated that indicators were used for the characterization of the baseline, environmental assessment, definition of the monitoring programme and public participation. ER indicators were presented in the SR for all the RBDA and in the NTS for nearly all RBDA (except for RH9). In some cases, the indicators used in the ER were not exactly coincident with the indicators proposed in the SR.

\section{Conclusions}

Indicators are considered a major tool to support SEA and planning processes, and are used for different purposes, including characterization, evaluation, monitoring, communication and decision-making. Indicators are adopted to add value, to transform complex information and to convey messages with meaning for decisionmakers and for the public.

The conducted research provides an understanding of the profile of indicators used to support water resources planning and SEA in the Portuguese case of water resources planning and management. Overall, the analysed RBMP and SEA processes were mainly supported by indicators, and some of those indicators overlapped between the two processes. The indicators were mainly selected by the technical teams involved in the planning processes and SEA, and aimed to respond to water planning and management objectives, through characterization, evaluation and follow-up of the planning actions.

The analysed documents used a large number of indicators, mostly quantitative, and adopted very different approaches for their organization, selection and validation. Usually no participatory process was used in this context. Overall, the SEA themes'vulnerabilities and risks' and 'resources', and the planning themes 'water quality' and 'water quantity', presented the highest number of indicators.
The indicators used in these processes were mainly a result of non-structured procedures, showing the need to clarify several aspects. Several indicator issues and procedures, such as the indicator selection stage, remain to be further explored. There remain doubts regarding the criteria used in the selection of indicators, as well as the degree of stakeholder engagement in the selection process. The size of the data series, the availability and the management model should also be analysed since they are fundamental aspects of the success of indicator usage in planning and SEA processes.

Further research work should be conducted on the consultation of the stakeholders involved in the planning and SEA processes. Interviews addressing the different actors involved in the planning and SEA processes are one way to use their knowledge to promote process improvements by identifying criteria or sets of indicators to be used. Active stakeholder engagement throughout the entire process of indicator development, including design, implementation, operation and review/updating, is a key aspect to pursue and explore. The commitment to the use of standardized and more cross-cutting indicators between the planning and SEA processes is another recommendation for planners to consider. Also, for identical planning objectives in different RBD, it would be interesting to use similar indicators. The current research points to a set of critical indicators that could be used as a common framework in water management plans and SEA reports that could support comparative analysis of common water planning issues. However, future research is also needed to explore this area, including how to link common and specific tailor-made indicators, and how to operationalize it in practice.

\section{Note}

1. $\mathrm{RH}$ and $\mathrm{ARH}$ are the Portuguese acronyms for RBD and RBDA, respectively.

\section{Acknowledgements}

The authors gratefully acknowledge support from the Center for Environmental and Sustainability Research (CENSE). CENSE is funded through the Strategic Project Pest-OE/AMB/ UI4085/2013, of the Fundação para a Ciência e Tecnologia, Portugal. The authors also wish to thank the helpful comments from the editor and two anonymous reviewers.

\section{Disclosure statement}

No potential conflict of interest was reported by the authors.

\section{Funding}

This work was supported by the Center for Environmental and Sustainability Research (CENSE). CENSE is funded through the Strategic Project Pest-OE/AMB/UI4085/2013, of the Fundação para a Ciência e Tecnologia, Portugal. 


\section{ORCID}

Rosa Santos Coelho (D) http://orcid.org/0000-0001-9928-1436 Pedro S. Coelho (iD http://orcid.org/0000-0002-7525-3112

Tomás B. Ramos (iD http://orcid.org/0000-0002-8270-4022

Paula Antunes (iD http://orcid.org/0000-0002-9461-2328

\section{References}

Antunes P, Kallis G, Videira N, Santos R. 2009. Participation and evaluation for sustainable river basin governance. Ecol Econ. 68:931-939.

Birkmann J. 2003. Measuring sustainable spatial planning in Germany: indicator-based monitoring at the regional level. Built Environ. 29:296-305.

Birkmann J. 2007. Risk and vulnerability indicators at different scales: applicability, usefulness and policy implications. Environ Hazards. 7:20-31.

Bockstaller C, Girardin P. 2003. How to validate environmental indicators. Agric Syst. 76:639-653.

Bonde J, Cherp A. 2000. Quality review package for strategic environmental assessments of land-use plans. Impact Assess Proj Apprais. 18:99-110.

Bryman A. 2012. Social research methods. 4th ed. New York (NY): Oxford University Press.

Carter J, Howe J. 2006. The water framework directive and the strategic environmental assessment directive: exploring the linkages. Environ Impact Assess Rev. 26:287-300.

Christian-Smith J, Gleick PH, Cooley H, Allen L, Vanderwarker A, Berry KA. 2012. A twenty-first century U.S. water policy. New York (NY): Oxford University Press.

Cloquell-Ballester VA, Cloquell-Ballester VA, Monterde-Díaz R, Santamarina-Siurana MC. 2006. Indicators validation for the improvement of environmental and social impact quantitative assessment. Environ Impact Assess Rev. 26:79105.

da Silva AWL, Selig PM, Van Bellen HM. 2014. Use of sustainability indicators in strategic environmental assessment processes conducted in Brazil. J Environ Assess Policy Manag. 16:1450008-1-26.

da Silva AWL, Selig PM, Morales ABT. 2012. Indicadores de sustentabilidade em processos de avaliação ambiental estratégica. Ambient Soc. 15:75-96.

d'Auria L, Cinnéide M. 2009. Integrating strategic environmental assessment into the review process of a development plan in Ireland. Impact Assess Proj Apprais. 27:309-319.

Donnelly A, Jennings E, Mooney P, Finnan J, Lynn D, Jones M, O'Mahony T, Thérivel R, Byrne G. 2006a. Workshop approach to developing objectives, targets and indicators for use in SEA. J Environ Assess Policy Manag. 8:135-156.

Donnelly A, Jones M, O'Mahony T, Byrne G. 2006b. Decisionsupport framework for establishing objectives, targets and indicators for use in strategic environmental assessment. Impact Assess Proj Apprais. 24:151-157.

Donnelly A, Jones M, O'Mahony T, Byrne G. 2007. Selecting environmental indicator for use in strategic environmental assessment. Environ Impact Assess Rev. 27:161-175.

Donnelly A, Prendergast T, Hanusch M. 2008. Examining quality of environmental objectives, targets and indicators in environmental reports prepared for strategic environmental assessment. J Environ Assess Policy Manag. 10:381-401.

European Communities. 2009. Common implementation strategy for the water framework directive (2000/60/EC). Official Journal of the European Communities. Guidance document 21. Luxembourg; p. 73.
European Commission. 2013. River basin network on water framework directive and agriculture. Joint Research Centre of the European Commission Report; Luxembourg; p. 266.

European Environment Agency. 2005. EEA core set of indicators. Technical report 1, p. 38. Luxembourg.

European Parliament. 2000. Directive 2000/60/EC of the European Parlamient and of the Council of 23 October 2000, establishing a framework for community action in the field of water policy. Off J Eur Communities. 327:1-73.

European Parliament. 2001. Directive 2001/42/EC of the European Parliament and of the Council of 27 June 2001, on the assessment of the effects of certain plans and programmes on the environment. Off J Eur Communities. 197:30-37.

Falck WE, Spangenberg JH. 2014. Selection of social demandbased indicators: EO-based indicators for mining. J Clean Prod. 84:193-203.

Fischer TB. 2003. Strategic environmental assessment in postmodern times. Environ Impact Assess Rev. 23:155-170.

Fischer, TB. 2007. The theory and practice of strategic environmental assessment: towards a more systematic approach. London: Earthscan.

Fischer TB, Phylip-Jones J. 2008. Scoping in environmental assessment. In: Fischer TB, Gazzola P, Jha-Thakur U, Belcáková I, Aschemann R, editors. Environmental assessment lecturers' handbook. [place unknown]: TwoEAM. p. 137-167

Fraser EDG, Dougill AJ, Mabee WE, Reed M, McAlpine P. 2006. Bottom up and top down: analysis of participatory processes for sustainability indicator identification as a pathway to community empowerment and sustainable environmental management. J Environ Manage. 78:114-127.

Gallopin G. 1996. Environmental and sustainability indicators and the concept of situational indicators: a systems approach. Environ Model Assess. 1:101-117.

Gallopin G. 1997. Indicators and their use: information for decision-making. In: Moldan B, Billharz S, editors. Sustainability indicators: report of the project on indicators of sustainable development. SCOPE 58. Wiley, Chichester; p. 13-27.

Gao J, Christensen P, Kørnøv L. 2014. The changing Chinese SEA indicator guidelines: top-down or bottom-up? Environ Impact Assess Rev. 44:22-30.

Gao J, Kørnøv L, Christensen P. 2010. Comparative study of SEA experiences between EU and China: the use of indicators. EASY-ECO Conf Sustain Dev Eval Eur Brussels, Brussels, 1-13.

Gao J, Kørnøv L, Christensen P. 2013a. Do indicators influence communication in SEA? - Experience from the Chinese practice. Environ Impact Assess Rev. 43:121-128.

Gao J, Kørnøv L, Christensen P. 2013b. The politics of strategic environmental assessment indicators: weak recognition found in Chinese guidelines. Impact Assess Proj Apprais. 31:232-237.

GAO (United States General Accounting Office). 1996. Content analysis: a methodology for structuring and analyzing written material. Washington (DC) GAO; p. 77.

Garfi M, Ferrer-Martí L. 2011. Decision-making criteria and indicators for water and sanitation projects in developing countries. Water Sci Technol. 64:83-101.

Gleick PH. 2003. Water use. Annu Rev Environ Resour. 28:275314.

Gleick PH. 2014. The world's water. Volume 8: the biennial report on freshwater resources. In: Gleick PH, editor. Washington (DC): Island Press; p. 496.

Gonzalez A, Donnelly A, Jones M, Klostermann J, Groot A, Breil M. 2011. Community of practice approach to developing urban sustainability indicators. J Environ Assess Policy Manag. 13:591-617. 
Gudmundsson H, Joumard R, Aschemann R, Tennøy A. 2010. Indicators and their functions. In: Indicators of environmental sustainability in transport. An interdisciplinary approach to methods. [place unknown]. Bron: Institut national de recherche sur les transports et leur sécurité - INRETS; $p$. 23-43.

Helbron H, Schmidt M, Glasson J, Downes N. 2011. Indicators for strategic environmental assessment in regional land use planning to assess conflicts with adaptation to global climate change. Ecol Indic. 11:90-95.

Juwana I, Muttil N, Perera BJC. 2012. Indicator-based water sustainability assessment - a review. Sci Total Environ. 438:357-371.

Krippendorff K. 2003. Content analysis: an introduction to its methodology. 2nd ed. Thousand Oaks, CA: Sage.

Kurtz JC, Jackson LE, Fisher WS. 2001. Strategies for evaluating indicators based on guidelines from the Environmental Protection Agency's Office of Research and Development. Ecol Indic. 1:49-60.

Larsen SV, Kørnøv L. 2009. SEA of river basin management plans: incorporating climate change. Impact Assess Proj Apprais. 27:291-299.

Lei $n^{\circ}$ 58/2005 29 de Dezembro. 2005. Diário da República $1^{\text {a }}$ série, 249, 29 Dezembro. [in Portuguese].

Mascarenhas A, Nunes LM, Ramos TB. 2015. Selection of sustainability indicators for planning: combining stakeholders' participation and data reduction techniques. J Clean Prod. 92:295-307.

Mascarenhas A, Ramos TB, Nunes L. 2012. Developing an integrated approach for the strategic monitoring of regional spatial plans. Land Use Policy. 29:641-651.

Matondo Jl. 2002. A comparison between conventional and integrated water resources planning and management. Phys Chem Earth. 27:831-838.

Morse S. 2013. Bottom rail on top: the shifting sands of sustainable development indicators as tools to assess progress. Sustainability. 5:2421-2441.

Morse S. 2015. Developing sustainability indicators and indices. Sustain Dev. 23:84-95.

Neuendorf KA. 2002. The content analysis guidebook. Thousand Oaks, CA: Sage.

Niemeijer D. 2002. Developing indicators for environmental policy: data-driven and theory-driven approaches examined by example. Environ Sci Policy. 5:91-103.

Niemeijer D, de Groot RS. 2008. A conceptual framework for selecting environmental indicator sets. Ecol Indic. 8:14-25.

Norton RK. 2008. Using content analysis to evaluate local master plans and zoning codes. Land Use Policy. 25:432454.

OECD. 1993. OECD core set of indicators for environmental performance reviews a synthesis report by the group on the state of the environment. Organisation for economic co-operation and development. Paris. Report No. 83, p. 39.

OECD. 2000. Towards sustainable development: indicators to measure progress. Organisation for economic cooperation and development. Proceedings of the OECD Rome conference. Paris; p. 417.
OECD. 2003. OECD environmental indicators development, measurement and use. Organisation for economic cooperation and development. Reference paper, Paris; p. 37.

OECD. 2006. Applying strategic environmental assessment: good practice guidance for development co-operation. Paris: OECD Publishing.

Partidário MR. 2012. Guia de melhores práticas para avaliação ambiental estratégica - orientações metodológicas para um pensamento estratégico em AAE. Lisboa: Agência Portuguesa do Ambiente; p. 76.

Polido A, Ramos TB. 2015. Towards effective scoping in strategic environmental assessment. Impact Assess Proj Apprais. 3:171-183.

Portaria 1284/2009 19 de Outubro. 2009. Diário da República $1^{\text {a }}$ série, 202. [in Portuguese].

Ramos TB. 2009. Development of regional sustainability indicators and the role of academia in this process: the Portuguese practice. J Clean Prod. 17:1101-1115.

Ramos TB, Caeiro S. 2010. Meta-performance evaluation of sustainability indicators. Ecol Indic. 10:157-166.

Ramos TB, Caeiro S, de Melo JJ. 2004. Environmental indicator frameworks to design and assess environmental monitoring programs. Impact Assess Proj Apprais. 22:47-62.

RIVM/UNEP. 1997. The future of the global environment: A model-based analysis supporting UNEP's first global environment outlook. Bakkes J, van Woerden J, editors. RIVM 402001007 and UNEP/DEIA/TR.97-1.

Savenije HHG, Van der Zaag P. 2008. Integrated water resources management: concepts and issues. Phys Chem Earth. 33:290297.

Schmidt M, Joao E, Albrecht E. 2005. Implementing strategic environmental assessment. Berlin: Springer.

Schomaker M. 1997. Development of environmental indicators in UNEP. In: Paper presented at the land quality indicators and their use in sustainable agriculture and rural development, January 25-26. FAO, Rome; p. 35-36.

Therivel, R. 2004. Strategic environmental assessment in action. Earthscan, editor. London: Earthscan.

Valenzuela Montes LM, Matarán Ruiz A. 2008. Environmental indicators to evaluate spatial and water planning in the coast of Granada (Spain). Land Use Policy. 25:95-105.

van-Doren D, Driessen PPJ, Schijf B, Runhaar HC. 2013. Evaluating the substantive effectiveness of SEA: towards a better understanding. Environ Impact Assess Rev. 38:120-130.

Wong C. 2005. Indicators for urban and regional planning the interplay of policy and methods. Hague C, Richardson T, Uplon R, editors. New York (NY): Routledge.

World Bank. 2007. Strategic environmental assessment and integrated water resources management and development. Economic and sector work environment department. World Bank. June 29. Washington (DC); p. 164.

World Bank. 2011. Strategic environmental assessment in policy and sector reform: conceptual model and operational guidance. International bank for reconstruction and development / World bank, University of Gothenburg, Swedish University of agricultural sciences, Netherlands commission for environmental assessment, Washington (DC); p. 240. 